\title{
Growth characteristics of Escherichia coli 0157:H7 on sliced meat at temperature abuse conditions
}

\author{
Osman Erkmen \\ Department of Food Engineering Faculty of Engineering University of Gaziantep, Gaziantep 27310 Turkey. \\ Accepted 29 March, 2013

\begin{abstract}
This study investigated the growth and survival of Escherichia coli 0157:H7 and aerobic bacteria (AB) in air (AP), vacuum (VP) and modified atmosphere packed (MAP) with sliced meat stored at 4, 6, 8 and $12^{\circ} \mathrm{C}$. A slight reduction in the numbers of $E$. coli $0157: \mathrm{H} 7$ was observed after 21 days at $4^{\circ} \mathrm{C}$ in the VP and MAP sliced meat while significant $(p<0.05)$ growth of bacterium was observed with storage temperature increased from 6 to $12^{\circ} \mathrm{C}$ in all packed sliced meats. Growth of $A B$ was observed during storage from 4 to $12^{\circ} \mathrm{C}$ in all packed sliced meats. Lag phase duration of $E$. coli O157:H7 and $A B$ at 4$12^{\circ} \mathrm{C}$ were significantly $(p<0.05)$ higher in the AP sliced meat than VP and MAP. The growth rates of $E$. coli $0157: \mathrm{H} 7$ and $A B$ on the sliced meat stored at $6-12^{\circ} \mathrm{C}$ were significantly $(p<0.05)$ higher than those of $E$. coli $0157: \mathrm{H7}$ stored at $4^{\circ} \mathrm{C}$. Temperature control is very important to ensure no growth of $E$. coli 0157:H7 on the sliced meat with modification of storage atmosphere.
\end{abstract}

Key words: Escherichia coli O157:H7, aerobic bacteria, meat, vacuum packaging, modified atmosphere packaging, temperature.

\section{INTRODUCTION}

The increase in world population and change in lifestyles have resulted in demands on animal origin foods. Foods may be contaminated by different pathogenic and spoilage microorganisms causing food spoilage and human health problems (Erkmen and Bozoglu, 2008b). Escherichia coli makes up a large proportion of the intestinal microflora of gastrointestinal tract of animals. The vehicle of $E$. coli O157: $\mathrm{H} 7$ infection was thought to be meat and meat products from a butcher's shop (Dykes et al., 2001). Surface cross-contamination of foodborne pathogens in food products during processing or preparation is a major concern to consumers and food manufacturers. Although risk assessment and analyses have been applied to monitor and reduce the hazards (Graumann and Holley, 2007; Erkmen and Bozoglu, 2008b). Pathogenic E. coli strains have emerged as an important pathogen, causing worldwide disease and economic loss. The infection caused by E. coli $\mathrm{O} 157: \mathrm{H} 7$ has been reported from many countries
(Mead and Griffin, 1998; Arias et al., 2001; Blanco et al., 2003).

Surface foodborne pathogen transfer during slicing is one of the important factors to impact the food safety in preparing sliced meat. A slicer is commonly used and most likely to be the last preparation step before packaging or wrapping of the meat products. These products are available in the supermarket refrigeration section and produced either by brand-named manufacturers or in store preparation, including made-to-order. Sliced meats are also commonly sold in delicatessen and fast food restaurants, where a retail-scale slicer is often used on site for meal or sandwich preparations. The slicing equipment, if not properly cleaned and sanitized, can cause microbial cross-contamination (Dubal et al., 2004; Perez-Rodriguez et al., 2007; Erkmen and Bozoglu, 2008b).

Chilled storage of fresh beef under vacuum or carbon dioxide $\left(\mathrm{CO}_{2}\right)$ atmospheres is used commercially to extend 
product storage (Erkmen and Bozoglu, 2008a). Pathogen behavior on raw meats, as with many other foods, is controlled by several interrelated factors, such as temperature of storage, atmosphere composition and competitive microflora(ICMSF, 1998; ErkmenandBarazi,2008; Erkmen and Bozoglu, 2008a). The current assumption is that $E$. coli $\mathrm{O} 157: \mathrm{H} 7$ does not multiply below $7^{\circ} \mathrm{C}$, which is the endpoint generally accepted by the European Union as an appropriate temperature to prevent mesophilic pathogen growth (Anon, 2004). However, conditions at both retail and wholesale level can provide an opportunity for numbers to increase because of temperature abuse or temperature fluctuations (ICMSF, 2002; Zhou et al., 2010). E. coli $\mathrm{O} 157: \mathrm{H} 7$ is a potential contaminant in the environment especially when the slicing equipment/ operation involve multiple products (Graumann and Holley, 2007). In this study, the growth characteristics of $E$. coli O157:H7 and aerobic bacteria $(A B)$ in air, vacuum and modified atmosphere packed sliced meat stored at different temperatures $\left(4,6,8\right.$ and $\left.12^{\circ} \mathrm{C}\right)$ were investigated. The growth parameters were also indicated to describe the survival of $E$. coli $\mathrm{O} 157: \mathrm{H} 7$ and $\mathrm{AB}$ during storage of packed sliced meat.

\section{MATERIALS AND METHODS}

\section{Escherichia coli 0157:H7 preparation}

A cocktail of two strains was used for the surface contamination of E. coli O157:H7 on sliced meat. E. coli O157:H7 NCTC 12900 and NCTC 13126 were obtained from The National Collection of Type Cultures (Porton Down, Salisbury, SP4 0JG, UK). Each strain was transferred from a stock culture kept at $-27^{\circ} \mathrm{C}$ into $10 \mathrm{ml}$ of brain heart infusion broth (BHIB; Difco, Detroit) and incubated at $35^{\circ} \mathrm{C}$ for $18 \mathrm{~h}$. Zero-point $1 \mathrm{ml}$ of each culture was also transferred into another ten $\mathrm{ml} \mathrm{BHIB}$ and again incubated at $35^{\circ} \mathrm{C}$ for $18 \mathrm{~h}$. Ten $\mathrm{ml}$ of each $E$. coli O157: $\mathrm{H} 7$ culture was mixed together in a $5 \mathrm{~L}$ bottle containing sterile $0.1 \%$ peptone water $(\mathrm{PW})$. That was used as $E$. coli $\mathrm{O} 157: \mathrm{H} 7$ contamination culture. The number of $E$. coli $\mathrm{O} 157: \mathrm{H} 7$ in contamination culture was counted by spread plating $1 \mathrm{ml}$ of sample in duplicate onto the surface of sorbitol-MacConkey agar plates supplemented with cefixime $\left(0.5 \mathrm{mg} \mathrm{l}^{-1}\right)$ and potassium tellurite $\left(2.5 \mathrm{mg} \mathrm{I}^{-1}\right)$ (CT-SMAC, Oxoid, USA). The number of $E$. coli O157:H7 in contamination culture was about $3.84 \times 10^{4}$ colony forming units $(\mathrm{cfu}) / \mathrm{ml}$. Contamination culture was used for contaminating $E$. coli $\mathrm{O} 157: \mathrm{H} 7$ to surface area of sliced meat. A separate contamination culture was prepared for each replicate.

\section{Meat preparation, packaging and storage conditions}

Fresh sliced raw beef meat (average cross-cut surface approximately $6 \times 3 \mathrm{~cm}$ with approximately $0.5 \mathrm{~cm}$ thick) with $14 \%$ fat was obtained from a local butcher and transported to the laboratory in cooler boxes containing ice packs. The initial $\mathrm{pH}$ of sliced meat was about 5.72 .

Samples of sliced meat from each replicate were screened for the presence of naturally occurring $E$. coli O157:H7 using the following procedures. Briefly, $25 \mathrm{~g}$ of sliced meat was added into $500 \mathrm{ml}$ flask containing $225 \mathrm{ml}$ sterile EC (E. coli) broth (Oxoid, USA) supplemented with $0.02 \mathrm{mg} \mathrm{ml}^{-1}$ novobiocin (Sigma-Aldrich, USA) and incubated for $18-24 \mathrm{~h}$ at $37^{\circ} \mathrm{C}$. Then, the culture was streaked out onto CT-SMAC plates and incubated for $18-24 \mathrm{~h}$ at $37^{\circ} \mathrm{C}$.
Sorbitol-negative colonies were streaked for purity and screened by the indole test and other confirmation tests for $E$. coli $0157: \mathrm{H} 7$ (Erkmen, 2007).

About five $\mathrm{kg}$ sliced meat pieces were contaminated by immersion in the $10 \mathrm{~L}$ bottle containing contamination culture for $2 \mathrm{~min}$. The contents of bottle were filtered through sterile cheesecloth under aseptic conditions and then meat pieces were placed into other sterile cheesecloth and allowed to drain for $5 \mathrm{~min}$. The E. coli O157: $\mathrm{H} 7$ contamination level on sliced meat was about $5.25 \times 10^{2} \mathrm{cfu} / \mathrm{g}$. About $40 \mathrm{~g}$ of $E$. coli O157:H7 contaminated sliced meat was placed into sterile polyethylene/polyamide film (PE/PE) (Polinas Plastic Industry and Trade Inc., Manisa, Turkey) packages $(20 \times 12 \mathrm{~cm})$ under aseptic condition. According to the manufacturer's data, PE/PA film has permeability at $25^{\circ} \mathrm{C}$; oxygen: $160 \mathrm{~cm}^{3} \mathrm{~m}^{-2} \mathrm{day}^{-1}$ and water vapor: $8.5 \mathrm{~g} \mathrm{~m}^{-2} \mathrm{day}^{-1}$. The E. coli $\mathrm{O} 157: \mathrm{H} 7$ contaminated sliced meat was (i) air packed (AP), (ii) vacuum packed (VP) and (iii) modified atmosphere packed (MAP) $\left(10 \% \mathrm{O}_{2}+40 \% \mathrm{CO}_{2}+50 \% \mathrm{~N}_{2}\right)$ in vacuum packing machine (La Minerra, D.V.P. Vacuum Tech-nology, s.r.l., Italy) within $5 \mathrm{~min}$ at $20^{\circ} \mathrm{C}$. The $\mathrm{CO}_{2}, \mathrm{O}_{2}$ and $\mathrm{N}_{2}$ were mixed using Witt-Gas mixer ( $\mathrm{GmbH}$ and $\mathrm{Co} \mathrm{Kg}$, Deutschland) and the gas mixture was flushed into vacuum machine during packaging. Control packages were also prepared from non-contaminated sliced meat (without E. coli O157:H7 contamination). At least 10 packages from each packaging type were stored at each 4,6 and $8^{\circ} \mathrm{C}$ for 21 days, and at $12^{\circ} \mathrm{C}$ for 16 days with a relative humidity of $85-90 \%$.

\section{Sampling and microbiological analysis}

Two packages from each packaging type were taken on sampling days during storage. The sampling frequency was every $12 \mathrm{~h}$ at the beginning of storage and on 5, 10, 16 and 21 days of storage after growth of E. coli O157:H7 was observed. E. coli $\mathrm{O} 157: \mathrm{H} 7$ and $\mathrm{AB}$ were counted from sliced meat samples using the following procedures. Briefly, $25 \mathrm{~g}$ of sliced meat from package was added into $500 \mathrm{ml}$ flask containing $225 \mathrm{ml}$ sterile $0.1 \% \mathrm{PW}$, the flask was placed to a shaker (ST-402, Nüve, Industry and Equipment Manufacturing and Trade Inc., İstanbul) and shaked for $5 \mathrm{~min}$. Sample dilutions were spread-plated in duplicate on CT-SMAC and brain heart infusion agar (BHIA; Difco, Detroit), and plates were incubated at $35^{\circ} \mathrm{C}$ for $24 \mathrm{~h}$ to count $E$. coli $\mathrm{O} 157: \mathrm{H} 7$ and $\mathrm{AB}$ respectively. The $\mathrm{AB}$ counts from control meat samples (without E. coli O157:H7 inoculation) and before inoculation E. coli 0157:H7 onto the sliced meats were also determined. Characteristic colorless (or neutral/ gray) smoky center in 1-2 mm diameter colonies from plates containing 30 to 300 colonies were counted as E. coli O157:H7 (Erkmen, 2007). Least three characteristic E. coli O157:H7 colonies per plate are confirmed by morphological and biochemical tests (Erkmen, 2007). All bacterial colonies from BHIA plates were counted from plates. The number of survivors was expressed as log cfu/g. Each experimental condition was repeated three times. Each value represents the mean of six values (duplicate values for each sample analyzed from three independent trials).

\section{Growth parameters of $E$. coli $0157: \mathrm{H} 7$ and $A B$ on the sliced meat}

The model selected is a three-phase line one that divides the growth curve into the lag, exponential and stationary growth phases by using SigmaPlot v.10 for windows (Statsoft, Chicago IL, USA). During the lag phase, the cells are assumed to be replicating, as they adapt themselves to their new environment. Once adapted, the cells begin to grow at a rate that is maximal for the microorganism in the specific environment. During the exponential growth phase, the specific growth rate assumed to be a constant $(\mu=k)$ with the log time. Once the stationary phase has been reached, there is no net increase in number and the specific growth rate returns to zero $(\mu=$ 


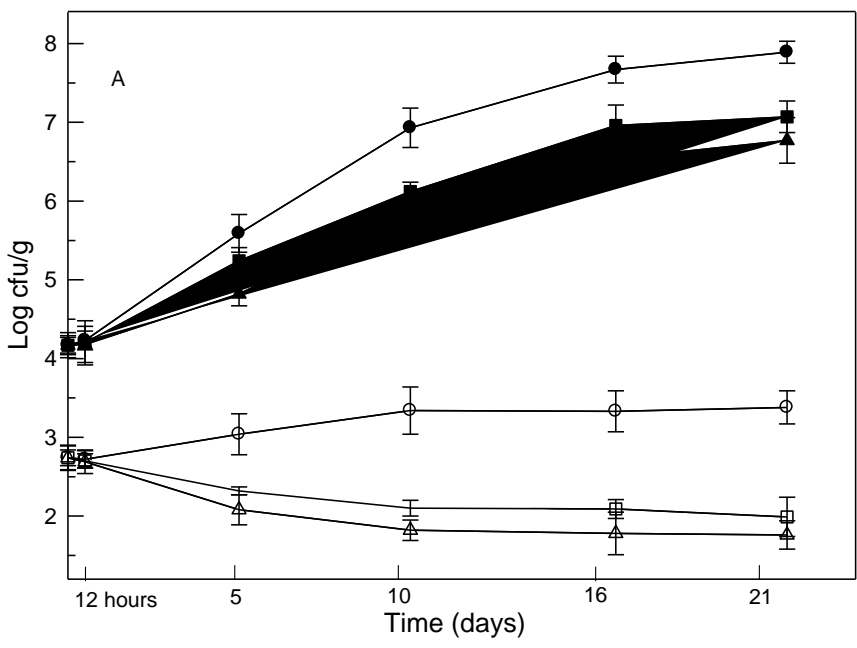

A

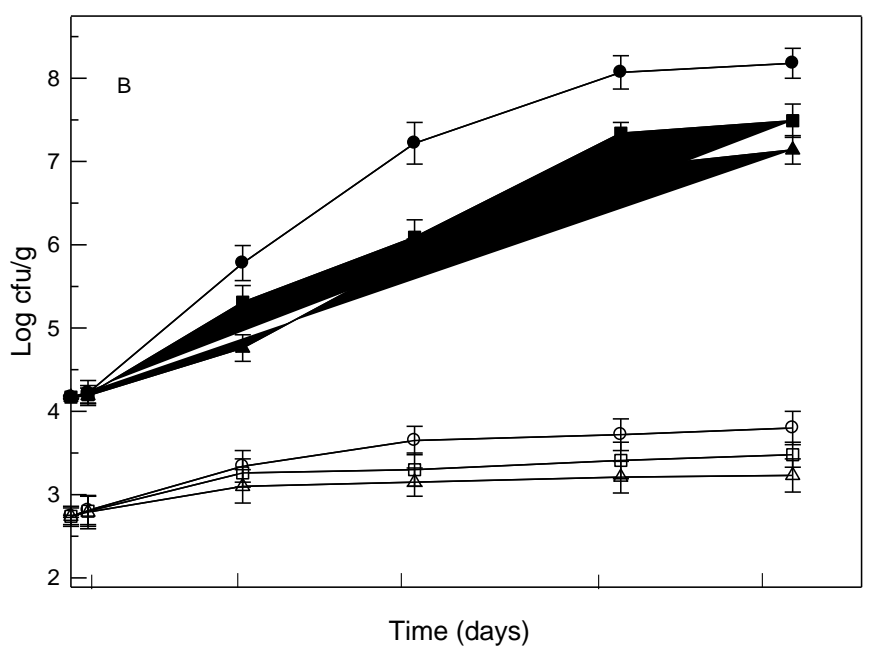

B

Figure 1. Growth of $E$. coli $\mathrm{O} 157: \mathrm{H} 7$ and aerobic bacteria $(\mathrm{AB})$ during storage in the packed sliced meat at $4^{\circ} \mathrm{C}(\mathrm{A})$ and $6^{\circ} \mathrm{C}(\mathrm{B})$. (o)

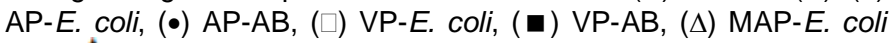
and $(\boldsymbol{\Lambda})$ MAP-AB.

0) (Buchanan et al., 1997; Erkmen and Bozoglu, 2008a; Hwang and Sheen, 2011). The numbers (log cfu/g) of $E$. coli O157:H7 and $A B$ on the sliced meat during storage at $4,6,8$ and $12^{\circ} \mathrm{C}$ were used to obtain the lag phase duration (LPD, h), growth rate (GR, log cfu/h) and maximum microbial number (MMN, log cfu/g):

Lag phase: For $t \leq t_{\text {lag }}, N_{t}=N_{0}$,

Exponential growth phase: For $t_{\text {lag }}<t<t_{\max }, G R=\left(N_{t}-N_{0}\right) /\left(t-t_{\text {lag }}\right)$, Stationary phase: For $\mathrm{t} \geq \mathrm{t}_{\max }, \mathrm{N}_{\mathrm{t}}=\mathrm{N}_{\max }$,

Where $N_{0}$ is the initial numbers (log cfu/g), $N_{t}$ is the bacterial numbers at time $t(h), N_{\max }$ is the maximum bacterial numbers, $t_{\text {lag }}$ is the lag phase duration $(h), t_{\max }$ is the time required for bacterial numbers to reach the maximum $\left(\mathrm{N}_{\max }\right)$.

\section{Statistical analysis}

Microbiological data were statistically analyzed (mean, standard deviation, variance and correlation coefficient) using the SigmaPlot v.10. Analysis of variance (ANOVA) of the data was carried out on the mean logarithmic to the base $10 \mathrm{cfu} / \mathrm{g}$ at each temperature-time for packed sliced meat at the $95 \%$ confidence level. Analysis of variance was applied to the parameters (GRs, LPDs and MMNs of $E$. coli $0157: \mathrm{H} 7$ and $\mathrm{AB}$ ) to determine statistical differences using the t-test among and between different storage conditions (temperatures, packaging types and storage period).

\section{RESULTS}

\section{Growth of E. coli O157:H7 and AB on the sliced meat}

E. coli $\mathrm{O} 157: \mathrm{H} 7$ was not detected on any un-inoculated sliced meat. The $\mathrm{pH}$ of sliced meat samples at the end of storage were 0.3-0.5 higher than the initial $\mathrm{pH}$. The initial numbers of $E$. coli $\mathrm{O} 157: \mathrm{H} 7$ and $\mathrm{AB}$ on the sliced meat were 2.74 and $4.17 \log \mathrm{cfu} / \mathrm{g}$ respectively. The changes in the number of microorganisms were very low at $4,6,8$ and $12^{\circ} \mathrm{C}$ after $12 \mathrm{~h}$ storage in the AP, VP and MAP sliced meat (Figures 1 and 2).

At $4^{\circ} \mathrm{C}$, no growth of $E$. coli $\mathrm{O} 157: \mathrm{H} 7$ was observed in the VP and MAP sliced meat (Figure 1A). It was slightly $(0.64 \mathrm{cfu} / \mathrm{g})$ increased after 21 days of storage in the AP sliced meat. Slight reduction in the number of $E$. coli O157: $\mathrm{H} 7$ was observed during storage, as the initial level of the bacterium decreased to 1.99 and $1.76 \mathrm{log} \mathrm{cfu} / \mathrm{g}$ in the VP and MAP sliced meat respectively after 21 days. There were no significant $(p>0.05)$ differences in the number of $E$. coli $\mathrm{O} 157: \mathrm{H} 7$ in the VP and MAP sliced meat during storage.

At $6^{\circ} \mathrm{C}$, the growth of $E$. coli $\mathrm{O} 157: \mathrm{H} 7$ was observed in the AP, VP and MAP sliced meat during 21 days storage (Figure 1B), as the E. coli O157:H7 counts increased to $3,80,3.48$ and 3.23 log cfu/g respectively. During 3 days storage, the levels of $E$. coli $\mathrm{O} 157: \mathrm{H} 7$ remained constant in the AP sliced meat. During the next 7 days, growth was slightly increased and then remained constant. There were no significant $(p>0.05)$ differences in the number of $E$. coli O157:H7 during 21 days storage in the AP, VP and MAP sliced meat.

At $8^{\circ} \mathrm{C}$, constant growth of $E$. coli $\mathrm{O} 157: \mathrm{H} 7$ was observed in the AP, VP and MAP sliced meat during 21 days storage (Figure $2 \mathrm{~A}$ ), as the $E$. coli $\mathrm{O} 157: \mathrm{H} 7$ counts increased to $5.18,4.47$ and $4.18 \mathrm{log} \mathrm{cfu} / \mathrm{g}$ respectively. The levels of $E$. coli O157:H7 remained constant during 3 days, increased during next 7 days and slower during remaining storage period. Significant $(p<0.05)$ growth of E. coli O157:H7 was observed in the AP, VP and MAP sliced meat during 21 days storage. In the AP sliced meat, E. coli $0157: \mathrm{H} 7$ counts were significantly $(p<0.05)$ higher than those observed in the VP and MAP sliced meat. This indicated that the absence of air in the package reduced the growth of the pathogen.

At $12^{\circ} \mathrm{C}$, growth of $E$. coli $\mathrm{O} 157: \mathrm{H} 7$ was observed in the AP, VP and MAP sliced meat during 16 days storage 


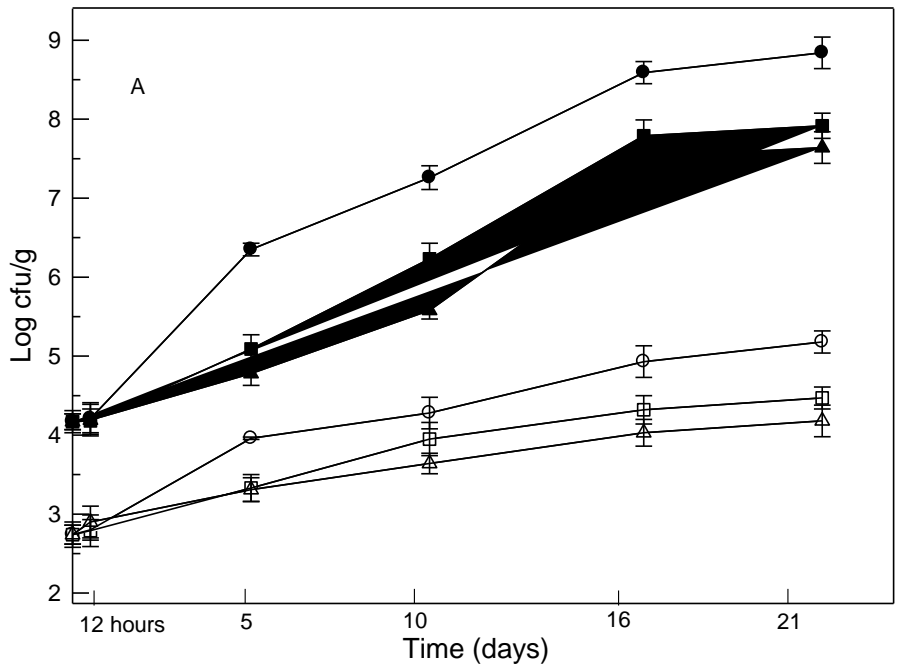

A

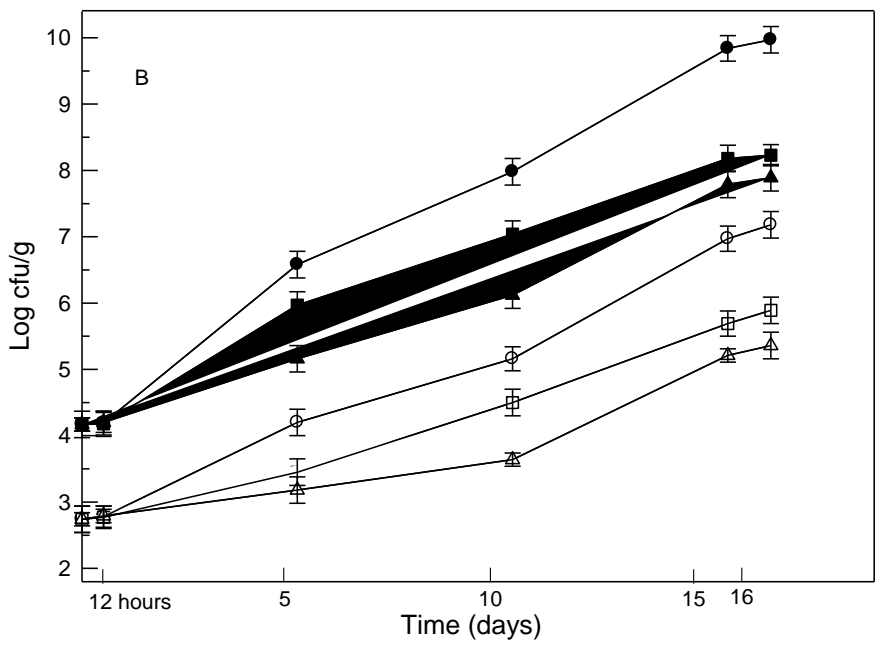

B

Figure 2. Growth of $E$. coli $\mathrm{O} 157: \mathrm{H} 7$ and aerobic bacteria $(\mathrm{AB})$ during storage in the packed sliced meat at $8^{\circ} \mathrm{C}(\mathrm{A})$ and $12^{\circ} \mathrm{C}(\mathrm{B})$.

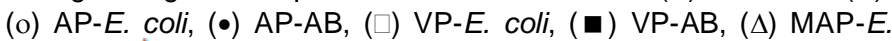
coli and $(\boldsymbol{\Lambda})$ MAP-AB.

(Figure 2B). Significant $(p<0.05)$ growth of E. coli 0157 : $\mathrm{H} 7$ was observed in all packed sliced meat. The growth of $E$. coli O157: $\mathrm{H} 7$ was higher in the AP sliced meat than the VP and MAP. By the day 16, E. coli O157:H7 numbers reached their highest number in the AP, VP and MAP sliced meat, as increased to $7.18,5.89$ and $5.36 \mathrm{log}$ cfu/g respectively.

At $4^{\circ} \mathrm{C}$ (Figure $1 \mathrm{~A}$ ), the number of $A B$ was remained constant during 3 days of storage in the AP, VP and MAP sliced meat while slight growth was observed at $6^{\circ} \mathrm{C}$ (Figure 1B). There was rapid increase during next 13 days and the growth was slower in last 5 days. $A B$ counts increased when the temperature increased from 4 to $6^{\circ} \mathrm{C}$. The highest number of $A B$ was observed $(p<0.05)$ in $A P$ sliced meat than VP and MAP, as increased to 8.18, 7.49 and $7.14 \log \mathrm{cfu} / \mathrm{g}$, respectively, at $6^{\circ} \mathrm{C}$ after 21 days. This indicated that the absence of air in the package can reduced the growth of $A B$. Significant $(p<0.05)$ growth of $A B$ was observed in the AP, VP and MAP sliced meat during 21 days storage at $6^{\circ} \mathrm{C}$. Significant $(p<0.05)$ differences on the growth of $A B$ were between 4 and $6^{\circ} \mathrm{C}$.

Under 8 (Figure $2 \mathrm{~A}$ ) and $12^{\circ} \mathrm{C}$ (Figure 2B) storage, the growth of $A B$ continuously increased during storage period in all packed sliced meat. However, the growth remained constant in the last 5 days at $8^{\circ} \mathrm{C}$ and 2 days at $12^{\circ} \mathrm{C}$. The numbers of $A B$ increased to $9.97,8.23$ and $7.89 \mathrm{log} \mathrm{cfu} / \mathrm{g}$ at $12^{\circ} \mathrm{C}$ after 16 days in the AP, VP and MAP sliced meat, respectively, while the numbers increased to $8.84,7.91$ and $7.64 \log \mathrm{cfu} / \mathrm{g}$ at $8^{\circ} \mathrm{C}$ in the AP, VP and MAP sliced meat, respectively. The increase in the AP sliced meat was significantly $(p<0.05)$ higher than the VP and MAP sliced meat. Growth of $A B$ at $12^{\circ} \mathrm{C}$ was significantly $(p<0.05)$ higher than at $8^{\circ} \mathrm{C}$ in all packages.

\section{Growth characteristics of $E$. coli $0157: \mathrm{H} 7$ and $A B$ on the sliced meat}

The LPDs of E. coliwere $75,69,50$ and $37 \mathrm{~h}$ in the AP sliced meat stored at $4,6,8$ and $12^{\circ} \mathrm{C}$, respectively (Table 1). In the VP sliced meat, the LPDs of E. coli O157: $\mathrm{H} 7$ were 81 , 72,55 and $42 \mathrm{~h}$ at respective temperatures. The LPDs of E. coli $0157: \mathrm{H} 7$ were not significantly $(\mathrm{p}>0.05)$ different at all storage temperatures of the AP, VP and MAP sliced meat. The GRs for E. coli O157:H7 in the VP and MAP sliced meat stored from 4 to $12^{\circ} \mathrm{C}$ were ranged from 0.0015 to 0.0063 and -0.0019 to $0.0052 \log \mathrm{cfu} / \mathrm{h}$, respectively (Table 1 ) while packed with air was ranged from 0.0013 to $0.0088 \mathrm{log} \mathrm{cfu} / \mathrm{h}$. The GRs of E. coli O157:H7 or $A B$ in the packed sliced meat stored at 6,8 and $12^{\circ} \mathrm{C}$ were significantly higher $(p<0.05)$ than at $4^{\circ} \mathrm{C}$. The GRs of $E$. coli $\mathrm{O} 157: \mathrm{H} 7$ and $\mathrm{AB}$ in the each type of packed sliced meat were significantly $(p<0.05)$ increased with the temperature increase from 4 to $12^{\circ} \mathrm{C}$. During storage at $12^{\circ} \mathrm{C}$, the MMNs of $E$. coli $\mathrm{O} 157: \mathrm{H} 7$ and $\mathrm{AB}$ is reached to 7.18 and $9.97 \log \mathrm{cfu} / \mathrm{g}$, respectively, in the AP sliced meat. The MMNs of E. coli O157:H7 were 3.23, 4.18 and $5.36 \mathrm{log} \mathrm{cfu} / \mathrm{g}$ on the MAP sliced meat stored at 6,8 and $12^{\circ} \mathrm{C}$ respectively.

\section{DISCUSSION}

The growth characteristics of E. coli $\mathrm{O} 157: \mathrm{H} 7$ and $\mathrm{AB}$ on the packed sliced meat were influenced by the modified atmospheres and storage temperatures. The growth of $E$. coli $\mathrm{O} 157: \mathrm{H} 7$ occurred at $6-12^{\circ} \mathrm{C}$ with populations increase 
Table 1. Means of the LPD (h), GR (log10 cfu/h) and MMN (log10 cfu/g) (standard deviation) of E. coli O157:H7 and aerobic bacteria $(A B)$ in the packed sliced meat stored at $4-12^{\circ} \mathrm{C}$.

\begin{tabular}{|c|c|c|c|c|c|c|c|c|c|c|}
\hline \multirow{2}{*}{$\begin{array}{c}\text { Temperature } \\
\left({ }^{\circ} \mathrm{C}\right)\end{array}$} & \multirow{2}{*}{$\begin{array}{l}\text { Microbial } \\
\text { Count }\end{array}$} & \multicolumn{3}{|c|}{ AP } & \multicolumn{3}{|c|}{ VP } & \multicolumn{3}{|c|}{ MAP } \\
\hline & & LPD & GR & MMN & LPD & GR & MMN & LPD & GR & MMN \\
\hline \multirow[b]{2}{*}{4} & E. coli & $\begin{array}{l}75 \\
(4)\end{array}$ & $\begin{array}{c}0.0013 \\
(0.0003)\end{array}$ & $\begin{array}{c}3.38 \\
(0.31)\end{array}$ & $\begin{array}{l}81 \\
(2)\end{array}$ & $\begin{array}{l}-0.0015^{*} \\
(0.0001)\end{array}$ & $\begin{array}{c}1.99 \\
(0.42)\end{array}$ & $\begin{array}{l}84 \\
(4)\end{array}$ & $\begin{array}{l}-0.0019 \\
(0.0002)\end{array}$ & $\begin{array}{c}1.76 \\
(0.08)\end{array}$ \\
\hline & $A B$ & 72 & $\begin{array}{c}0.0074 \\
(0.0001)\end{array}$ & $\begin{array}{c}7.89 \\
(0.42)\end{array}$ & $\begin{array}{l}76 \\
(7)\end{array}$ & $\begin{array}{c}0.0058 \\
(0.0002)\end{array}$ & $\begin{array}{l}7.07 \\
(0.26)\end{array}$ & $\begin{array}{l}78 \\
(2)\end{array}$ & $\begin{array}{c}0.0052 \\
(0.0001)\end{array}$ & $\begin{array}{l}6.77 \\
(0.12)\end{array}$ \\
\hline \multirow{2}{*}{6} & E. coli & $\begin{array}{l}69 \\
(3)\end{array}$ & $\begin{array}{c}0.0021 \\
(0.0001)\end{array}$ & $\begin{array}{c}3.80 \\
(0.26)\end{array}$ & $\begin{array}{l}72 \\
(4)\end{array}$ & $\begin{array}{c}0.0015 \\
(0.0002)\end{array}$ & $\begin{array}{c}3.48 \\
(0.40)\end{array}$ & $\begin{array}{l}71 \\
(4)\end{array}$ & $\begin{array}{c}0.0010 \\
(0.0003)\end{array}$ & $\begin{array}{c}3.23 \\
(0.34)\end{array}$ \\
\hline & $A B$ & $\begin{array}{l}67 \\
(1)\end{array}$ & $\begin{array}{c}0.0080 \\
(0.0002)\end{array}$ & $\begin{array}{c}8.18 \\
(0.31)\end{array}$ & $\begin{array}{l}69 \\
(3)\end{array}$ & $\begin{array}{c}0.0066 \\
(0.0003)\end{array}$ & $\begin{array}{c}7.49 \\
(0.26)\end{array}$ & $\begin{array}{l}68 \\
(6)\end{array}$ & $\begin{array}{c}0.0059 \\
(0.0004)\end{array}$ & $\begin{array}{l}7.14 \\
(0.29)\end{array}$ \\
\hline \multirow{2}{*}{8} & E. coli & $\begin{array}{l}50 \\
(7)\end{array}$ & $\begin{array}{c}0.0049 \\
(0.0002)\end{array}$ & $\begin{array}{l}5.18 \\
(0.25)\end{array}$ & $\begin{array}{l}55 \\
(6)\end{array}$ & $\begin{array}{c}0.0034 \\
(0.0001)\end{array}$ & $\begin{array}{c}4.47 \\
(0.32)\end{array}$ & $\begin{array}{l}54 \\
(3)\end{array}$ & $\begin{array}{c}0.0029 \\
(0.0002)\end{array}$ & $\begin{array}{l}4.18 \\
(0.12)\end{array}$ \\
\hline & $A B$ & $\begin{array}{l}46 \\
(4)\end{array}$ & $\begin{array}{c}0.0093 \\
(0.0004)\end{array}$ & $\begin{array}{l}8.84 \\
(0.43)\end{array}$ & $\begin{array}{l}53 \\
(1)\end{array}$ & $\begin{array}{c}0.0074 \\
(0.0004)\end{array}$ & $\begin{array}{c}7.91 \\
(0.18)\end{array}$ & $\begin{array}{l}51 \\
(1)\end{array}$ & $\begin{array}{c}0.0069 \\
(0.0001)\end{array}$ & $\begin{array}{l}7.64 \\
(0.27)\end{array}$ \\
\hline \multirow{2}{*}{12} & E. coli & $\begin{array}{l}37 \\
(5)\end{array}$ & $\begin{array}{c}0.0088 \\
(0.0116)\end{array}$ & $\begin{array}{l}7.18 \\
(0.51)\end{array}$ & $\begin{array}{l}42 \\
(5)\end{array}$ & $\begin{array}{c}0.0063 \\
(0.0002)\end{array}$ & $\begin{array}{c}5.89 \\
(0.12)\end{array}$ & $\begin{array}{l}44 \\
(1)\end{array}$ & $\begin{array}{c}0.0052 \\
(0.0004)\end{array}$ & $\begin{array}{l}5.36 \\
(0.28)\end{array}$ \\
\hline & $A B$ & $\begin{array}{l}36 \\
(4)\end{array}$ & $\begin{array}{c}0.0167 \\
(0.0009)\end{array}$ & $\begin{array}{l}9.97 \\
(0.23)\end{array}$ & $\begin{array}{l}39 \\
(2)\end{array}$ & $\begin{array}{c}0.0081 \\
(0.0011)\end{array}$ & $\begin{array}{l}8.239 \\
(0.36)\end{array}$ & $\begin{array}{l}40 \\
(2)\end{array}$ & $\begin{array}{c}0.0074 \\
(0.0012)\end{array}$ & $\begin{array}{l}7.89 \\
(0.34)\end{array}$ \\
\hline
\end{tabular}

*Minus (-) indicates reduction.

from 2.74 to $\geq 3.80, \geq 3.48$ and $\geq 3.23 \mathrm{log} \mathrm{cfu} / \mathrm{g}$ in the AP, VP and MAP sliced meat respectively. AB displayed similar growth patterns during storage periods. The packaging of the sliced meat with $\mathrm{CO}_{2}$ and vacuum reduced the GRs and MMNs of $E$. coli and $\mathrm{AB}$, and the influence diminished with the temperature increases. E. coli O157:H7 did not grow at $4^{\circ} \mathrm{C}$ in the VP and MAP sliced meat over 21 days of storage. The population showed an inactivetion rate of -0.0015 and $-0.0019 \mathrm{log} / \mathrm{h}$.

Temperature is probably the most important extrinsic factor affecting the growth and viability of microorganisms. Tamplin et al. (2005) reported the growth of E. coli 0157: $\mathrm{H7}$ at $6^{\circ} \mathrm{C}$ on the raw ground beef. During commercial storage, temperatures may fluctuate and opportunities exist for temperature abuse. At $4^{\circ} \mathrm{C}$, an increase of $E$. coli $\mathrm{O} 157: \mathrm{H} 7$ was observed as the initial level of the bacterium rose by $0.48 \mathrm{log} \mathrm{cfu} / \mathrm{g}$ after the 12 days holding period of lamp chops under aerobic condition (Barrera et al., 2007). Barkocy-Gallagher et al. (2002) observed minor increases for six E. coli O157:H7 strains on the ground beef held at $4^{\circ} \mathrm{C}$ for 14 days under aerobic condition, they significantly increased (between 0.9 and $1.5 \mathrm{log} \mathrm{cfu} / \mathrm{g}$ ) at $7^{\circ} \mathrm{C}$. Many studies reported that $E$. coli $\mathrm{O} 157: \mathrm{H} 7$ on the inoculated raw meat significantly $(p<0.05)$ increased at a temperature ranging from 10 to $15^{\circ} \mathrm{C}$ under aerobic conditions (Berry and Koohmaraie, 2001; Li and Logue, 2005; Tamplin et al., 2005; Barrera et al., 2007). In the present study, an increase of E. coli O157:H7 was observed as the initial level of the bacterium rose by $0.37 \log \mathrm{cfu} / \mathrm{g}$ after 21 days storage at $4^{\circ} \mathrm{C}$ under aerobic condition.

Along with temperature, atmosphere gas composition is a major environmental factor that can influence microbial growth. The simplest form of modified atmosphere packaging is the vacuum packaging. In this study, the VP sliced meat storage at $4^{\circ} \mathrm{C}$ for 21 days resulted in a slight decrease $(0.75 \mathrm{log} \mathrm{cfu} / \mathrm{g})$ of $E$. coli $\mathrm{O} 157: \mathrm{H} 7$ number while decrease was higher in MAP (0.78 log cfu/g). Two gases, $\mathrm{CO}_{2}$ and $\mathrm{N}_{2}$ are commonly used in MAP, the first being mainly responsible for the bacteriostatic or bactericidal effect on microorganisms. For meat and meat products, red color maintenance is important (Erkmen and Barazi, 2008; Erkmen and Bozoglu, 2008a). During storage of $E$. coli $\mathrm{O} 157: \mathrm{H} 7$ inoculated sliced meat at $4^{\circ} \mathrm{C}$ in $30 \% \mathrm{CO}_{2}$ atmosphere, the pathogen showed significant $(p<0.05)$ reduction compared to similar conditions in air. To inhibit growth of spoilage and pathogenic bacteria and increase shelf life, retailers can use modification of atmosphere. E. coli O157: $\mathrm{H} 7$ shows growth at or over $6^{\circ} \mathrm{C}$ and is most relevant for packed meat and meat products (Rao and Sachindra, 2002; Barrera et al., 2007).

The present study shows that the prolonged shelf life at $4^{\circ} \mathrm{C}$ did not increase the risk of $E$. coli $\mathrm{O} 157: \mathrm{H} 7$ on the sliced meat stored with the vacuum or $\mathrm{CO}_{2}$ packaging without the temperature abuse. This is probably due to the anaerobic conditions and high $\mathrm{CO}_{2}$ that is inhibitory to E. coli O157:H7. The growth of E. coli O157:H7 in the VP 
and MAP sliced meat from 6 to $12^{\circ} \mathrm{C}$ does however emphasize the importance of temperature control during storage. There is a wide range of temperature criteria for chilled foods at retail in European countries. The values range from -1 to $10^{\circ} \mathrm{C}$, with most temperatures being between 4 and $8^{\circ} \mathrm{C}$ (European Commission, 1996). These aspects should also be considered together with the conclusions of the study, which states that modification of atmosphere has proven to enhance the product quality by inhibiting the spoilage and pathogenic bacteria. The data from this study add to the vast growth/survival data of $E$. coli $\mathrm{O} 157: \mathrm{H} 7$ on the sliced meat as effected by the storage temperature, modified atmosphere, and product handling and storage conditions. Temperature control is very important to ensure no growth of $E$. coli O157:H7 on the sliced meat with modification of storage atmosphere. Results from this study add to the understanding of the behavior of E. coli O157:H7 on the sliced meat and hence further enhance the safety of food prepared from this meat.

\section{ACKNOWLEDGEMENT}

This research was supported by Gaziantep University Research Fond.

\section{REFERENCES}

Anon (2004). Regulation (EC) No 853/2004 of the European Parliament and of the Council of 29 April 2004 laying down specific hygiene rules for food of animal origin. Off. J. Eur. Union, L226:22-82.

Arias ML, Monge-Rojes R, Chaves C, Antillon F (2001). Effect of storage temperatures on the growth and survival of Escherichia coli O157:H7 inoculated in foods from a neotropical environment. Rev. Biol. Trop. 49(2): 517-524.

Barkocy-Gallagher GA, Kang D-H, Koohmaraie M (2002). Fate of field isolated Escherichia coli $\mathrm{O} 157$ in ground beef at different storage temperatures. J. Food Prot. 65: 1106-1109.

Barrera O, Rodríguez-Calleja JM, Santos JA, Otero A, Garcia-Lopez M$L$ (2007). Effect of different storage conditions on E. coli O157:H7 and the indigenous bacterial microflora on lamb meat. Int. J. Food Microbiol. 115: 244-251.

Berry ED, Koohmaraie M (2001). Effect of different levels of beef bacterial microflora on the growth and survival of Escherichia coli 0157:H7 on beef carcass tissue. J. Food Prot. 64: 1138-1144.

Blanco M, Blanco JE, Mora A, Rey J, Alonso JM, Hermoso M, Hermoso J, Alonso MP, Dahbi G, González EA, Bernárdez MI, Blanco J (2003). Serotypes, virulence genes, and intimin types of Shiga toxin (verotoxin)-producing Escherichia coli isolates from healthy sheep in Spain. J. Clin. Microbiol. 41: 1351-1356.

Buchanan RL, Whiting RC, Damert WC (1997). When is simple good enough: a comparison of the Gompertz, Baranyi and three-phase linear models for fitting bacterial growth curves. Food Microbiol. 14: 313-326.

Dubal ZB, Paturkar AM, Waskar VS, Zende RJ, Latha C, Rawool DB, Kadam MM (2004). Effect of food grade organic acids on inoculated $S$. aureus, L. monocytogenes, $E$. coli and $S$. Typhimurium in sheep/goat meat stored at refrigeration temperature. Meat Sci. 66: 817-821.

Dykes GA, Moorhead SM, Roberts SL (2001). Survival of Escherichia coli 0157:H7 and Salmonella on chill-stored vacuum or carbon dioxide packaged primal beef cuts. Int. J. Food Microbiol. 64: 401405.
Erkmen O (2007). Basic Methods for the Microbiological Analysis of Foods. Nobel Publishing Company, Ankara.

Erkmen O, Barazi A (2008). Modelling the effects of modified atmosphere on Salmonella typhimurium in packaged meat during storage in the refrigerator and at $12^{\circ} \mathrm{C}$. Ann. Microbiol. 58(1): 73-81.

Erkmen O, Bozoglu TF (2008a). Food Microbiology 3: Food Preservation. İlke Publishing Company, Ankara.

Erkmen O, Bozoglu TF (2008b). Food Safety. İlke Publishing Company, Ankara.

European Commission (1996). Scientific co-operation on questions relating to food. Task 2.2: Studies relating to temperature control. Directorate-General III 10.5 .

Graumann GH, Holley RA (2007). Survival of Escherichia coli O157:H7 in needle-tenderized dry cured Westphalian ham. Int. J. Food Microbiol. 118: 173-179.

Hwang C-A, Sheen S (2011). Growth characteristics of Listeria monocytogenes as affected by a native microflora in cooked ham under refrigerated and temperature abuse conditions. Food Microbiol. 28: 350-355.

ICMSF (1998). Microorganisms in Foods. 6. Microbial Ecology of Food Commodities. Blackie Academic and Professional, London.

ICMSF (2002). Microorganisms in Foods 7: Microbiological Testing in Food Safety Management. Kluwer Academic/Plenum Publishers, New York.

Li QZ, Logue CM (2005). The growth and survival of Escherichia coli 0157:H7 on minced bison and pieces of bison meat stored at 5 and $10^{\circ} \mathrm{C}$. Food Microbiol. 22: 415-421.

Mead P, Griffin P (1998). Escherichia coli O157:H7. Lancet, 352: 12071212.

Perez-Rodriguez F, Valero A, Todd ECD, Carrasco E, Carcia-Gimeno RM, Zurera G (2007). Modeling transfer of Escherichia coli O157:H7 and Staphylococcus aureus during slicing of a cooked meat product. Meat Sci. 76: 692-699.

Rao DN, Sachindra NM (2002). Modified atmosphere and vacuum packaging of meat and poultry products. Food Rev. Int. 18(4): 263293.

Tamplin ML, Paoli G, Marmer BS, Phillips J (2005). Models of the behavior of Escherichia coli $\mathrm{O} 157: \mathrm{H} 7$ in raw sterile ground beef stored at 5 to $46^{\circ} \mathrm{C}$. Int. J. Food Microbiol. 100: 335-344.

Zhou GH, Xu XL, Liu Y (2010). Preservation technologies for fresh meat - Rev. Meat Sci. 86: 119-128. 